\title{
Implementation of a surgical safety checklist in Brazil: cross-sectional study
}

\author{
Implementação de checklist de segurança cirúrgica no Brasil: estudo transversal \\ Implementación de la lista de verificación de seguridad quirúrgica en Brasil: estúdio transversal
}

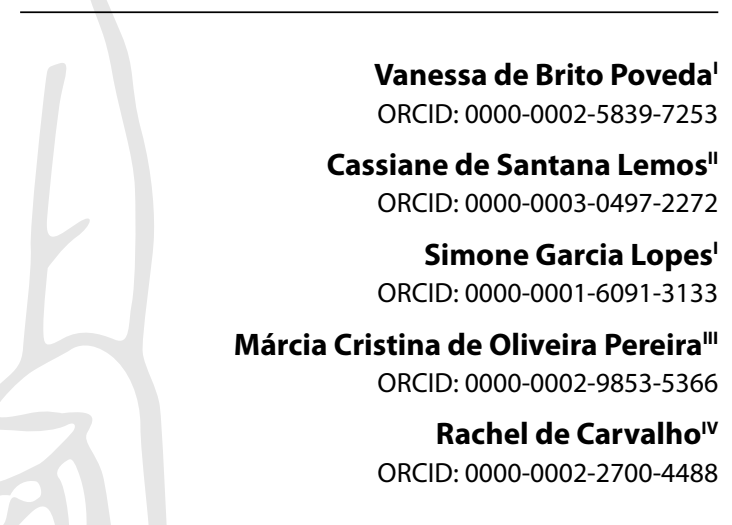

'Universidade de São Paulo. São Paulo, São Paulo, Brazil.

"Santa Casa de São Paulo. São Paulo, São Paulo, Brazil.

"' Hospital São Luiz. São Paulo, São Paulo, Brazil.

" Faculdade Albert Einstein. São Paulo, São Paulo, Brazil.

How to cite this article:

Poveda VB, Lemos SL, Lopes SG, Pereira MCO, Carvalho R. Implementation of a surgical safety

checklist in Brazil: a cross-sectional study.

Rev Bras Enferm. 2021;74(2):e20190874.

doi: http://dx.doi.org/10.1590/0034-7167-2019-0874

Corresponding author:

Vanessa de Brito Poveda

E-mail: vbpoveda@usp.br

EDITOR IN CHIEF: Antonio José de Almeida Filho ASSOCIATE EDITOR: Alexandre Bansanelli

Submission: $04-06-2020$

Approval: 09-21-2020

\begin{abstract}
Objective: to identify the implementation process of the World Health Organization Surgical Safety Checklist in Brazilian hospitals. Methods: this is a cross-sectional study with 531 participants during a Congress of Perioperative Nursing, promoted by the Brazilian Association of Operating Room Nurses, Anesthetic Recovery and Material and Sterilization Center, in 2017. Results: among the nursing professionals included, $84.27 \%$ reported the checklist implementation in the workplace. Regarding daily application in the Sign-in stage, $79.65 \%$ of professionals confirmed patient identification with two indicators; in the Timeout stage, $51.36 \%$ of surgeries started regardless of confirmation of one of the items. In the Sign-out stage, $69.34 \%$ of professionals did not count or occasionally counted the surgical instruments and suture needles, and only $36.36 \%$ reviewed concerns about postoperative recovery. Conclusion: this study identified needs for improvements in applying the checklist in the Brazilian reality, to guarantee safer surgical procedures.

Descriptors: Nurses; Patient Safety; Checklist; Perioperative Care; Risk Management.
\end{abstract}

\section{RESUMO}

Objetivo: identificar o processo de implantação da Lista de Verificação de Segurança Cirúrgica da Organização Mundial da Saúde em hospitais brasileiros. Métodos: estudo transversal com 531 participantes durante um Congresso de Enfermagem Perioperatória, promovido pela Associação Brasileira dos Enfermeiros de Centro Cirúrgico, Centro de Recuperação Anestésica e Material e Esterilização, em 2017. Resultados: dentre os profissionais de enfermagem incluídos, 84,27\% relataram a implantação do checklist no ambiente de trabalho. Em relação à aplicação diária na etapa Sign-in, 79,65\% dos profissionais confirmaram a identificação do paciente com dois indicadores; na etapa Time-out, $51,36 \%$ das cirurgias foram iniciadas independentemente da confirmação de um dos itens. Na etapa Sign-out, $69,34 \%$ dos profissionais não contaram ou ocasionalmente contaram os instrumentos cirúrgicos e agulhas de sutura. Apenas 36,36\% revisaram preocupações sobre a recuperação pós-operatória. Conclusão: este estudo identificou necessidades de melhorias na aplicação do checklist na realidade brasileira, para garantir procedimentos cirúrgicos mais seguros.

Descritores: Enfermeiras e Enfermeiros; Segurança do Paciente; Lista de Checagem; Assistência Perioperatória; Gestão de Riscos.

\section{RESUMEN}

Objetivo: identificar el proceso de implementación de la Lista de Verificación de Seguridad Quirúrgica de la Organización Mundial de la Salud en los hospitales brasileños. Métodos: estudio transversal con 531 participantes durante un Congreso de Enfermería Perioperatoria, promovido por la Asociación Brasileña de Enfermeras del Centro Quirúrgico, Centro de Recuperación y Esterilización de Anestesia y Material, en 2017. Resultados: entre los profesionales de enfermería incluidos, el 84,27\% informó la implementación de la lista de verificación en el lugar de trabajo. En cuanto a la aplicación diaria en la etapa de Sign-in, el $79,65 \%$ de los profesionales confirmaron la identificación del paciente con dos indicadores; en la etapa de Time-out, el $51,36 \%$ de las cirugías se iniciaron independientemente de la confirmación de alguno de los ítems. En la etapa de Sign-out, el 69,34\% de los profesionales no contaba u ocasionalmente el instrumental quirúrgico y las agujas de sutura. Solo el $36,36 \%$ revisó las preocupaciones sobre la recuperación postoperatoria. Conclusión: este estudio identificó necesidades de mejoras en la aplicación del checklist en la realidad brasileña, para asegurar procedimientos quirúrgicos más seguros.

Descriptores: Enfermeros y Enfermeras; Seguridad del Paciente; Lista de Verificación; Atención Perioperativa; Gestión de Riesgos. 


\section{INTRODUCTION}

The number of surgeries has progressively increased over the years, with an estimated 312,93 million procedures worldwide ${ }^{(1)}$. In this context, the operating room (OR) is a complex environment in which professionals need to work in teams to guarantee care quality and safety of for patients ${ }^{(2)}$.

Faced with morbidity and mortality rates associated with surgeries, in 2008, the World Health Organization (WHO) launched the "Safe Surgery Saves Lives" program, which proposed applying a three-step surgical safety checklist (Sign-in, Time-out, and Signout). Before beginning the surgery, the steps include checking the materials and equipment required, patients' airway conditions prior to anesthesia, staff member confirmation, critical moments of the anesthetic-surgical procedure, and antibiotic prophylaxis. Before leaving the OR, the steps included verifying possible failures occurred during the procedure, anatomopathological sample, review of patients' needs for postoperative recovery, as well as gauze, compress and needle count ${ }^{(3)}$.

In 2013, the Brazilian Ministry of Health approved a protocol for safe surgery, which guides the application of a checklist in all health establishments that perform procedures, inside or outside the OR, involving an incision in the human body or introduction of endoscopic equipment by any health professional. This action was aimed at preventing and reducing the incidence of adverse events, enhancing patient safety assurance ${ }^{(4-5)}$.

It should be emphasized that applying the checklist in health institutions reduces the number of postoperative complications, such as surgical site infection and reoperation, as well as a decrease in mortality associated with the surgical procedure $\mathrm{e}^{(6-7)}$. Additionally, application of the checklist during surgery improved communication among professionals and increased safety perception related to the provided care ${ }^{(2,8)}$.

Thus, the Brazilian Association of Operating Room Nurses, Anesthetic Recovery and Material and Sterilization Center (SOBECC - Sociedade Brasileira de Enfermeiros de Centro Cirúrgico, Recuperação Anestésica e Centro de Material e Esterilização) develops a mission of collaborating with technical-scientific development and dissemination of best practices for perioperative nursing in Brazil, sought to identify the WHO Surgical Safety Checklist implementation by nursing staff members in different hospitals in Brazil.

\section{OBJECTIVE}

This study aims to identify the implementation process of the WHO Surgical Safety Checklist in Brazilian hospitals.

\section{METHODS}

\section{Ethical aspects}

Nursing professionals attending the event and who worked at an OR were invited to participate in the study, and they agreed after signing the Informed Consent Form (ICF). The study was approved by a Research Ethics Committee.

\section{Study design, setting and sample}

This is a quantitative and cross-sectional study. Data collection was performed in September 2017 during the $13^{\text {th }}$ Brazilian Congress of Nursing in Operating Room, Anesthetic Recovery, Anesthetic Recovery and Material and Sterilization Center, conducted by SOBECC.

A non-probability sampling of nursing professionals was selected, with an inclusion of 531 nurses.

\section{Data collection}

We used an instrument composed of 20 closed questions based on the WHO Surgical Safety Checklist to collect data. Moreover, sociodemographic characteristics and professional data were collected. The instrument was submitted to face and content validity by three experts on perioperative nursing. The experts agreed with the content proposed and made minor rephrasing suggestions.

A pilot test was conducted with ten subjects prior to the actual collection period and not included in the final analysis sample, to verify the suitability of the instrument and the proposed collection method. On this occasion, minor adjustments were made in the question formulation, to improve comprehension.

The research subjects were guided into an auditorium, and the instrument questions were projected on a screen. Participants could select the answer of their choice through an electronic voting system, which released preliminary results after a 60 -second voting period. The information from this research served as a guide for further discussions at the event, with OR and quality experts.

\section{Data analysis}

Data were analyzed descriptively and utilizing absolute numbers and percentages.

\section{RESULTS}

The number of respondents varied between 531 and 280 subjects among the responses received per item, and so, the number of responses received for each assessed item is presented in the following tables.

Table 1 shows that participants came from all regions of the country, with emphasis on the Southeast (54.8\%). They were between 31 and 40 years old ( $45.4 \%$ ) and worked in an OR between one and five years (31.3\%) (Table 1).

Among the assessed professionals, 51.18\% reported working at a large institution, $34.05 \%$ of institutions were private, and $58.70 \%$ of sites did not have quality accreditation (Table 2).

Overall, $84.27 \%$ of participants reported implementing the WHO Surgical Safety Checklist, and $74.1 \%$ of professionals made changes in the material proposed by WHO.

Concerning the execution of items per step, according to the WHO proposal, it was observed in the Sign-in stage that none of the assessed items was fully verified, as can be seen in Table 3.

For the Time-out stage, it was found that this stage is performed mostly (74.77\%) by a nursing assistant or technician, a professional characterized as circulating in the room, and that nurses are the ones who perform this step in only $24.08 \%$ of situations. 
Table 1 - Sociodemographic characteristics, according to professional category, working region, age and working time in an operating room, Brazil, 2017

\begin{tabular}{|c|c|c|}
\hline Variables & $\mathbf{n}$ & $\%$ \\
\hline \multicolumn{3}{|c|}{ Professional category $(n=508)$} \\
\hline Nursing assistant & 1 & 0.19 \\
\hline Nursing technician & 20 & 3.93 \\
\hline Nurse & 487 & 95.86 \\
\hline \multicolumn{3}{|l|}{ Working region $(n=403)$} \\
\hline Northeast & 50 & 12.40 \\
\hline North & 20 & 4.96 \\
\hline Southeast & 223 & 55.33 \\
\hline South & 68 & 16.87 \\
\hline Center-west & 42 & 10.42 \\
\hline \multicolumn{3}{|l|}{ Age $(n=476)$} \\
\hline $21-30$ & 114 & 23.95 \\
\hline $31-40$ & 216 & 45.38 \\
\hline $41-50$ & 87 & 18.28 \\
\hline $51-60$ & 48 & 10.08 \\
\hline$>60$ & 11 & 2.31 \\
\hline \multicolumn{3}{|c|}{ Working time in operating room $(n=531)$} \\
\hline$<1$ year & 67 & 12.62 \\
\hline $1-5$ years & 166 & 31.26 \\
\hline 6-10 years & 127 & 23.92 \\
\hline $11-15$ years & 74 & 13.94 \\
\hline $16-20$ years & 38 & 7.16 \\
\hline $21-25$ years & 32 & 6.03 \\
\hline$>26$ years & 27 & 5.08 \\
\hline
\end{tabular}

Table 2 - Distribution of participants according to organization size, profile and accreditation, Brazil, 2017

\begin{tabular}{lcc}
\hline Variables & $\mathbf{n}$ & $\%$ \\
\hline Size ( $\mathrm{n}=508)$ & & \\
$\quad$ Small (up to 50 beds) & 48 & 9.45 \\
Medium (51-150 beds) & 137 & 26.97 \\
$\quad$ Large (151-500 beds) & 260 & 51.18 \\
$\quad$ Extra Large (501 or more) & 63 & 12.40 \\
Profile ( $\mathrm{n}=514)$ & & \\
$\quad$ Philanthropic & 123 & 23.93 \\
Public & 170 & 33.07 \\
Private & 175 & 34.05 \\
$\quad$ Mixed & 46 & 8.95 \\
National/International Accreditation $(\mathrm{n}=523)$ & & \\
$\quad$ Yes & 216 & 41.3 \\
No & 307 & 58.7 \\
\hline
\end{tabular}

In the Time-out stage, more than half of the sample stated that the presence of all staff members is only occasionally confirmed, and that the surgery is occasionally started without confirmation of one of the Time-out items for $51 \%$ of the sample. Patient identification, surgical site and procedure before its onset occur only occasionally in $46.09 \%$ of the sample (Table 4 ).

In the Sign-out stage, it is noteworthy that although $39.54 \%$ of professionals occasionally perform surgical instrument and suture needle counts, the most report always performing the counting of compresses and gauzes. As for postoperative management and recovery concerns of patients, $50.51 \%$ of participants occasionally review these concerns with an anesthesiologist (Table 5).

When questioned about the importance of implementing the checklist, 393 (99.49\%) professionals believe that applying checklist increases the safety of patients undergoing surgeries. However, when completing the checklist, only 52 (13.27\%) believed that they implemented $100 \%$ of the steps and items; 174
(44.39\%) considered that they reached 80\%; 98 (25\%) achieved $60 \%$ completeness of the checklist; $36(9.18 \%)$ reached $40 \%$; $32(8.16 \%)$ only reached $20 \%$ completeness.

Table 3 - Frequency of verifying and completing Sign-in stages according to patient identification, surgical site demarcation, allergy check, risk of blood loss and difficult airway, Brazil, 2017

\begin{tabular}{lcc}
\hline Variables & $\mathbf{n}$ & $\%$ \\
\hline $\begin{array}{l}\text { Verification of patient identification with two } \\
\text { indicators ( } \mathrm{n}=511 \text { ) }\end{array}$ & & \\
$\quad$ Totally filled-in & 407 & 79.65 \\
$\quad$ Partially filled-in & 82 & 16.05 \\
$\quad$ Not filled-in & 22 & 4.31 \\
Surgical site demarcation ( $\mathrm{n}=512)$ & & \\
$\quad$ Always demarcated & 202 & 39.45 \\
$\quad$ Occasionally demarcated & 226 & 44.14 \\
$\quad$ Not demarcated & 84 & 16.41 \\
Allergy verification ( $\mathrm{n}=511$ ) & & \\
$\quad$ Always assessed & 463 & 90.61 \\
$\quad$ Occasionally assessed & 44 & 8.61 \\
$\quad$ Not assessed & 4 & 0.78 \\
Risk of blood loss ( $\mathrm{n}=504)$ & & \\
$\quad$ Always assessed & 318 & 63.10 \\
$\quad$ Occasionally assessed & 164 & 32.54 \\
$\quad$ Not assessed & 22 & 4.37 \\
Difficult airway risk ( $\mathrm{n}=506$ ) & & \\
$\quad$ Always assessed & 300 & 59.29 \\
$\quad$ Occasionally assessed & 186 & 36.76 \\
$\quad$ Not assessed & 20 & 3.95 \\
\hline
\end{tabular}

Table 4 - Frequency of verifying Time-out stages, presence of staff members, patient identification, surgical site and procedure; assessment of the need for specific materials and concerns with anesthesia and surgery, Brazil, 2017

\begin{tabular}{|c|c|c|}
\hline Variables & $\mathbf{n}$ & $\%$ \\
\hline \multicolumn{3}{|c|}{$\begin{array}{l}\text { Confirmation of presence of all staff members } \\
(n=449)\end{array}$} \\
\hline Always assessed & 178 & 40.18 \\
\hline Occasionally assessed & 223 & 50.34 \\
\hline Not assessed & 48 & 9.48 \\
\hline \multicolumn{3}{|c|}{$\begin{array}{l}\text { Confirmation of patient identification, surgical } \\
\text { site and procedure }(n=447)\end{array}$} \\
\hline Always assessed & 138 & 30.87 \\
\hline Occasionally assessed & 206 & 46.09 \\
\hline Not assessed & 103 & 23.04 \\
\hline \multicolumn{3}{|c|}{$\begin{array}{l}\text { Need for special materials and equipment } \\
(\mathrm{n}=449)\end{array}$} \\
\hline Always assessed & 259 & 57.68 \\
\hline Occasionally assessed & 157 & 34.97 \\
\hline Not assessed & 33 & 7.35 \\
\hline \multicolumn{3}{|c|}{$\begin{array}{l}\text { Concerns about procedure and blood loss } \\
(\mathrm{n}=449)\end{array}$} \\
\hline Always assessed & 250 & 57.08 \\
\hline Occasionally assessed & 147 & 33.56 \\
\hline Not assessed & 41 & 9.36 \\
\hline \multicolumn{3}{|c|}{$\begin{array}{l}\text { Confirmation of antibiotic prophylaxis prior to } \\
\text { surgical incision }(n=438)\end{array}$} \\
\hline Always assessed & 266 & 60.73 \\
\hline Occasionally assessed & 136 & 31.05 \\
\hline Not assessed & 36 & 8.22 \\
\hline \multicolumn{3}{|c|}{$\begin{array}{l}\text { Beginning of surgery without confirmation of } \\
\text { any Time-out item }(n=449)\end{array}$} \\
\hline Always assessed & 112 & 25.34 \\
\hline Occasionally assessed & 227 & 51.36 \\
\hline Not assessed & 103 & 23.3 \\
\hline
\end{tabular}


Table 5 - Frequency of verifying the Sign-out steps, according to counting of instruments, needles, gauzes and compresses; identification of anatomopathological and patient concerns, Brazil, 2017

\begin{tabular}{lcc}
\hline Variables & $\mathbf{n}$ & $\%$ \\
\hline $\begin{array}{l}\text { Counting surgical instruments and suture } \\
\text { needles ( } \mathrm{n}=349 \text { ) }\end{array}$ & & \\
$\quad$ Always assessed & 107 & 30.66 \\
$\quad$ Occasionally assessed & 138 & 39.54 \\
$\quad$ Not assessed & 104 & 29.80 \\
Counting compresses and gauzes ( $\mathrm{n}=280)$ & & \\
$\quad$ Always assessed & 183 & 65.36 \\
$\quad$ Occasionally assessed & 74 & 26.43 \\
$\quad$ Not assessed & 23 & 8.21 \\
Identification anatomopathological (n=395) & & \\
$\quad$ Always assessed & 360 & 30.66 \\
$\quad$ Occasionally assessed & 26 & 39.54 \\
$\quad$ Not assessed & 9 & 29.80 \\
Anesthesiologist and nursing staff review & & \\
concerns for patient recovery and management & & \\
(n=396) & & \\
$\quad$ Always assessed & 144 & 36.36 \\
$\quad$ Occasionally assessed & 200 & 50.51 \\
$\quad$ Not assessed & 52 & 13.13 \\
\hline
\end{tabular}

\section{DISCUSSION}

The results demonstrated that although professionals recognize the importance of applying the checklist for patient safety, incomplete application of items occurs at all stages, which may favor adverse event occurrence. In this context, since the beginning of development safe surgery checklist, literature has shown that implementation of this tool provided positive outcomes in the postoperative period. Using the safety checklist in eight health institutions showed a reduction in postoperative complications, such as surgical site infection and reoperation, from $11 \%$ to $7 \%$, in addition to a decrease from $1.5 \%$ to $0.8 \%$ of mortality associated with the surgical procedure ${ }^{(9)}$.

In this regard, a retrospective study analyzing 233 cases of damage to patients, in ten years of otorhinolaryngological procedures before complete the safe surgery checklist implementation, pointed out that $84.3 \%$ of injuries were associated with the care offered, mainly being related to surgical technique, unnecessary procedures, retention of foreign bodies and infection ${ }^{(10)}$.

A survey showed that more than half of participants did not apply the checklist. The same evidence was observed in other studies, whose completeness of checklist steps varied between $34 \%$ and $68 \%{ }^{(7,11)}$. Assessment of 565 surgical procedures, performed in five hospitals in England, also verified the incomplete application of the checklist. Carrying out the Time-out step occurred in $64 \%$ of procedures and the Sign-out step in $68 \%$ of surgeries ${ }^{(10)}$.

When analyzing Time-out items, staff was incomplete in $43 \%$ of procedures; in $10 \%$ of surgeries patient identification and procedure was not confirmed; in $29 \%$ of procedures there was blood loss, and in $15 \%$ of cases antibiotic prophylaxis was not assessed. At the Sign-out stage, $36 \%$ of procedures did not review concerns about recovery and management of postoperative patients ${ }^{(11)}$.

Another investigation observed that the checklist's three steps were applied in only $62.1 \%$ of surgical procedures, and incomplete checklist execution was related to a $16.9 \%$ increase in the risk of complications after surgery. When analyzed individually, the Sign-in was performed in $64.4 \%$ of procedures, Time-out, in $34.4 \%$, and Sign-out, in $64.3 \%$ of surgeries ${ }^{(7)}$.

On the other hand, it should be noted that applying the checklist in the three stages proposed was associated with a lower risk of postoperative bleeding, reduced intraoperative transfusion, and a reduction in the number of infections due to antibiotic administration before surgical incision ${ }^{(12)}$.

Thus, it is important to mention that only implementing a safe surgery checklist does not guarantee its adequate performance, since professionals' perceptions and organizational factors can influence the appropriate use of a care tool.

The inadequate use of the checklist was associated to a lack of understanding by professionals about the stage's appropriate execution moment; the rush of surgeons to start the procedure, raising the impression that pausing for checklist delays the work development. Furthermore, not all professionals were attentive during the application time of the checklist ${ }^{(13)}$. On the other hand, using the safe surgery checklist improved communication and teamwork among professionals such as increased safety perception about patients, because all practitioners have the information about patients and features for care ${ }^{(14)}$.

Therefore, health organizations play a fundamental role in the educational orientation of health staff professionals, offering support for implementing care tools in daily routines and showing the importance of using safety measures ${ }^{(15-16)}$. The successful implementation of the checklist was associated to training and learning material promotion, leadership development for continuous monitoring and auditing the checklist use, clarity in the role of each professional in the staff and support for analyzing actual effectiveness of implementing the checklist ${ }^{(13,17)}$.

Since the daily application of the checklist in an OR has a positive impact on communication among professionals (surgeons, anesthesiologists, nurses) and safety in the OR, there are changes in the perceptions of teamwork and safety climate, thus constituting aspects that may influence a reduction in postoperative morbidity ${ }^{(2)}$.

\section{Study limitations}

This study demonstrates a limitation in absence of analyzing the causes of not completing the checklist items by professionals. Thus, it is important to develop future studies, which assess the limiting factors for correct execution of the checklist, as well as an analysis of the damage and complications generated by inappropriate use.

\section{Contributions to nursing and health}

The results of this study demonstrate a sample of the national reality, which can collaborate for implementing improvements by surgical staff, health institutions and responsible government agencies, in addition to pointing out future directions in terms of education and training to be conducted by SOBECC.

\section{CONCLUSION}

This study enabled us to identify that, despite recognizing the importance of the checklist for patient safety on the part of professionals, there are several fragile points in applying the 
checklist steps for Safe Surgery in Brazilian hospital institutions, especially those related to Time-out and Sign-out.

The following were highlighted as points to be improved: surgical demarcation; organization of materials and equipment; patient identification, surgical site and procedure confirmation; beginning surgery even though items have not been reviewed; counting of instruments and needles; and the review of postoperative concerns among the staff.

\section{REFERENCES}

1. Weiser TG, Haynes AB, Molina G, et al. Size and distribution of global volume surgery in 2012. Bull World Health Organ. 2016;94:201-209F. https://doi.org/10.2471/BLT.15.159293

2. Etherington $\mathrm{N}, \mathrm{Wu} \mathrm{M}, \mathrm{Cheng}$-Boivin $\mathrm{O}$, Larrigan S, Boet S. Interprofessional communication in the operating room: a narrative review to advance research and practice. Can J Anaesth. 2019 Oct;66(10):1251-1260. https://doi.org/10.1007/s12630-019-01413-9.

3. World Health Organization (WHO). Second global challenge for patient safety: safe surgeries save lives (WHO guidelines for safe patient surgery) [Internet]. Rio de Janeiro: OPAS; 2010 [cited 2018 Nov 13]. 211 p. Available from: http://bvsms.saude.gov.br/bvs/publicacoes/ seguranca_paciente_cirurgia_salva_manual.pdf Portuguese.

4. Ministério da Saúde (BR). Portaria no 1.377, de 9 de julho de 2013, Aprova os Protocolos de Segurança do Paciente [Internet]. 2013 [cited 2018 Nov 14]. Available from: http://bvsms.saude.gov.br/bvs/saudelegis/gm/2013/prt137709072013.html. Portuguese.

5. Ministério da Saúde (BR). Protocolo para cirurgia segura [Internet]. 2013 [cited 2018 Nov 15]. Available from: http://www20.anvisa.gov.br/ segurancadopaciente/index.php/publicacoes/category/cirurgias-seguras

6. Haugen AS, Wæhle HV, Almeland SK, Harthug S, Sevdalis N, Eide GE, et al. Causal analysis of world health organization's surgical safety checklist implementation quality and impact on care processes and patient outcomes: secondary analysis from a large stepped wedge cluster randomized controlled trial in Norway. Ann Surg. 2019;269(2):283-90. https://doi.org/10.1097/SLA.0000000000002584

7. Mayer EK, Sevdalis N, Rout S, Caris J, Russ S, Mansell J, et al. Surgical checklist implementation project: the impact of variable WHO checklist compliance on risk-adjusted clinical outcomes after national implementation: a longitudinal study. Ann Surg. 2016;263(1):58-63, https://doi. org/10.1097/SLA.0000000000001185

8. Haugen AS, Sevdalis N, Søfteland E. Impact of the World Health Organization Surgical Safety Checklist on Patient Safety. Anesthesiol. 2019;131(2):420-5, https://doi.org/10.1097/ALN.0000000000002674

9. Haynes AB, Weiser TG, Berry WR, Lipsitz SR, Breizat AH, Dellinger EP, et al. A surgical safety checklist to reduce morbity and mortality in a global population. N Engl J Med. 2009;360(5):491-9. https://doi.org/10.1056/NEJMsa0810119

10. Helmiö P, Blomgren K, Lehtivuori T, Palonen R, Aaltonen LM. Towards better patient safety in otolaryngology: characteristics of patient injuries and their relationship with items on the WHO Surgical Safety Checklist. Clin Otolaryngol. 2015;40(5):443-8. https://doi.org/10.1111/ coa.12396

11. Russ S, Shantanu R, Caris J, Mansell J, Davies R, Mayer E, et al. Measuring variation in use of the WHO Surgical Safety Checklist in the operating room: a multicenter prospective cross-sectional study. J Am Coll Surg. 2015;220(1):1-11.e4. https://doi.org/10.1016/j. jamcollsurg.2014.09.021

12. Haugen AS, Waehle HV, Almeland SK, Harthug S, Sevdalis N, Eide GE, et al. Causal analysis of Word Health Organization's surgical safety checklist implementation quality and impact on care processes and patient outcomes. Ann Surg. 2017;20(20):1-6. https://doi.org/10.1097/ SLA. 0000000000002584

13. Papadakis M, Meiwandi A, Grzybowski A. The WHO safer surgery checklist time out procedure revisited: Strategies to optimise compliance and safety. Int J Surg. 2019;69:19-22, https://doi.org/10.1016/j.jju.2019.07.006

14. Haynes AB, Weiser TG, Berry WR, Lipsitz SR, Breizat AH, Dellinger EP, et al. Changes in safety attitude and relationship to decreased postoperative morbidity and mortality following implementation of a checklist-based surgical safety intervention. BMJ Qual Saf. 2011;20(1):102-7. https://doi.org/10.1136/bmjqs.2009.040022

15. Algie CM, Mahar RK, Wasiak J, Batty L, Gruen RL, Mahar PD. Interventions for reducing wrong-site surgery and invasive clinical procedures. Cochrane Database Syst Rev. 2015;(3):CD009404, https://doi.org/10.1002/14651858.CD009404.pub3

16. Horvat L, Horey D, Romios P, Kis-Rigo J. Cultural competence education for health professionals. Cochrane Database Syst Rev. 2014;(5):CD009405. https://doi.org/10.1002/14651858.CD009405.pub2

17. Pattni N, Arzola C, Malavade A, Varmani S, Krimus L, Friedman Z. Challenging authority and speaking up in the operating room environment: a narrative synthesis. Br J Anaesth. 2019;122(2):233-44. https://doi.org/10.1016/j.bja.2018.10.056 